\title{
Modelling the effects of combining pre-erythrocytic vaccines against Plasmodium falciparum
}

\author{
Andrew Walker*, Sunetra Gupta \\ From Challanges in malaria research: Core science and innovation \\ Oxford, UK. 22-24 September 2014
}

\section{Background}

A high efficacy multi-stage multi-epitope malaria vaccine would be an invaluable weapon in the eradication of malaria. Currently, the best progress in subunit vaccine research has been seen in targeting pre-erythrocytic (PE) stages of the parasite. In phase IIa trials, RTS,S in adjuvant was capable of inducing sterile protection in $50 \%$ of individuals [1], and ME-TRAP in a heterologous prime-boost regime saw around $21 \%$ efficacy [2]. Here we present a mathematical model investigating the effects of combining these two approaches.

\section{Materials and methods}

A mathematical model was developed to describe Plasmodium falciparum parasite dynamics within an immunonaive host. The model was parameterised using data from non-vaccine recipients in Controlled Human Malaria Infection (CHMI) studies, and then used to study the effects of vaccine induced immune responses against the sporozoite and hepatocytic stages of the life cycle, and the effects of combining them.

\section{Results}

Using data from phase IIa trials of RTS,S [1] and METRAP [2], we predict that near total sterile protection can be achieved by combining these vaccines. Even very low efficacy $(<1 \%)$ vaccines are shown to combine to confer sterile protection in up to $43 \%$ of individuals.

\section{Conclusions}

We find a heterologous vaccine treatment to act synergistically: the efficacy of the combination far outweighs the sum of its parts. This suggests that a high efficacy multi-stage vaccine may well be within reach, and may utilise some of the tools presently available.
Published: 22 September 2014

\section{References}

1. Kester KE, Cummings JF, Ofori-Anyinam O, Ockenhouse CF, Krzych U, Moris P, Schwenk R, Nielsen RA, Debebe Z, Pinelis E, Juompan L, Williams J, Dowler M, Stewart VA, Wirtz RA, Dubois M, Lievens M, Cohen J, Ballou WR, Heppner DG Jr: Randomized, Double-Blind, Phase 2a Trial of Falciparum Malaria Vaccines RTS,S/AS01B and RTS,S/AS02A in Malaria-Naive Adults: Safety, Efficacy, and Immunologic Associates of Protection. J Infect Dis 2009, 200:337-346.

2. Ewer KJ, O'Hara GA, Duncan CJA, Collins KA, Sheehy SH, Reyes-Sandoval A, Goodman AL, Edwards NJ, Elias SC, Halstead FD, Longley RJ, Rowland R, Poulton ID, Draper SJ, Blagborough AM, Berrie E, Moyle S, Williams N, Siani L, Folgori A, Colloca S, Sinden RE, Lawrie AM, Cortese R, Gilbert SC, Nicosia A, Hill AVS: Protective CD8(+) T-cell immunity to human malaria induced by chimpanzee adenovirus-MVA immunisation. Nat Commun 2013, 4:2836.

doi:10.1186/1475-2875-13-S1-P90

Cite this article as: Walker and Gupta: Modelling the effects of combining pre-erythrocytic vaccines against Plasmodium falciparum. Malaria Journal 2014 13(Suppl 1):P90

Department of Zoology, University of Oxford, Oxford, UK

Submit your next manuscript to BioMed Central and take full advantage of:

- Convenient online submission

- Thorough peer review

- No space constraints or color figure charges

- Immediate publication on acceptance

- Inclusion in PubMed, CAS, Scopus and Google Scholar

- Research which is freely available for redistribution

Submit your manuscript at www.biomedcentral.com/submit
C Biomed Central 